\title{
Education Marginalization Of Bajo Children Based On Local Wisdom
}

\author{
Maemunah $^{1 *}$, St. Haniah ${ }^{2}$, Sam'un Mukramin ${ }^{3}$ \\ ${ }^{1,2,3}$ Sociology Education, University of Muhammadiyah Makassar, \\ South Sulawesi, Indonesia \\ * Corresponding author: \\ Email: murtalamaemunah@gmail.com
}

\begin{abstract}
.
Empowerment of education in a society that has limitations in all aspects, becomes a separate obstacle in efforts to eradicate the marginalization of education. This is one of the educational chaotics which is still experiencing fluctuations in the implementation of central policies which are regulated centrally and unilaterally without considering the local wisdom of each different region and resulting in a slump in the education of the Bajo Tribe children. This study uses descriptive qualitative with a case study approach of nine informants with data collection techniques of observation, interviews, and documentation and then analyzed. Strategies for alleviating the Marginalization of Education for Bajo Tribe children in North Kolaka Regency, namely: a) an effort to internalize the values believed by the community itself; b) empowerment through education based on local wisdom which includes: parental awareness of education, partisanship with government policies, and utilization of the environment for education.
\end{abstract}

Keywords: alleviation, marginalization, education, Bajo children.

\section{INTRODUCTION}

Limitations in the structure of potential capacity development, make community groups different from one another and result in being marginalized and not having social spaces contributing to increasing potential in the human resource sector and utilization of natural resources. Marginal condition as a situation indirectly to limit; limiting the role of certain groups, so that it can lead to a condition of a low standard of living for several people which we often call poverty [1]. The existence of impartiality towards marginalized communities makes groups imperfectly assimilated or marginalizes other groups so that they have a low position. This is often found in transitional communities or coastal areas that are still far from equitable development and increasing resources which affect the inequality of opportunity in obtaining proper education and welfare guarantees.

The world of education and children as part of the environment and development will be pawns in building a quality society and an adequate environment in shaping the character of a child. So the environment is a place where we interact with each other, the environment is also a place where a person can form his personality. Therefore, what is meant by marginal children here are children who are marginalized and do not have equal opportunities in obtaining the rights and obligations to learn and be taught, whereas, on the other hand, these opportunities exist and can be accessed if there is massive and structured equity.

Like the children of the Bajo Tribe fishing community in North Kolaka Regency, Southeast Sulawesi who lack attention and opportunities to receive an education. The problems faced are very complex both internally by the family, the community itself because of cultural mythologies and the impact of the economy [4], on the other hand, children should be allowed to develop and not be used as tools to support economic factors or be sold for the benefit of a group. Such children should be given social protection. Social protection is intended to prevent and manage risks from shocks and 
social vulnerabilities of a person, family, group, or community so that their survival can be met by minimum basic needs [4] and externally from local government support in providing access to good education.

Problems in the implementation of education in Sulaho Village are still lacking attention from various parties including the local government, which can be seen from the lack of educators, inadequate school facilities, the number of unemployed, lack of awareness and motivation from parents about the importance of education, and expectations of ideals. -aspirations to improve the pattern of life and welfare in the future. So with these complex problems, the education of the children of the Bajo Tribe fishing community does not go well like schools in general. In addition, the teaching staff is limited and less active because access to housing is so far, difficult, and steep. So this research reveals the problem of "Eradicating Marginalization of Bajo Tribe Children's Education Based on Local Wisdom" as part of the problems that make Bajo Tribe fishing communities have backwardness in development efforts and improving welfare as a result of the dichotomy of empowerment and special treatment from stakeholders.

\section{METHODS}

The research design in this study is descriptive qualitative [5]-[7] with a case study approach [8] to examine in depth a reality or event regarding efforts to reduce the marginalization of education for Bajo Tribe Children in North Kolaka Regency, Southeast Sulawesi. Informant criteria are determined purposive sampling based on the needs and suitability of the required information [8], [9] with a total of nine informants consisting of the district government, village officials, Bajo Tribe residents, and Bajo Tribe children themselves. Primary and secondary data sources [10] with data collection techniques through observation, interviews, and documentation [11] then perform data analysis with the stages of a) data reduction; b) data exposure; and c) conclusion drawing and verification [12], [13].

\section{RESULTS AND DISCUSSION}

Sulaho Village is one of the areas located in Lasusua District, North Kolaka Regency, Southeast Sulawesi Province has natural resources that can be developed and preserved, from several government programs, especially in the field of education, it has an Early Childhood Education School. Elementary School and Junior High School Satap, with various limitations, which if demographically the position of the area is very close to the Regency City. However, development and development are relatively slow and far behind the surrounding areas. This has become a critical problem for this to be reviewed from various aspects, especially in the meaning of the marginalization of society, more than that is the chaos of education which has not yet obtained a balance of roles and strategic positions as a forum for implementing changes in mindsets and lifestyles that lead to improvement. quality of human resources.

\section{a. The Marginalization Process of Education}

The "marginalist" theory put forward by some economists, assumes that individuals are rational economic agents, who always seek to maximize the "utilities" received in their productive activities and exchange relations, and that social order is the complex "result" of education. individual actions, they introduce the concepts of "marginal utility" and "marginal cost" to explain the allocation of resources to a predetermined goal (Scott, 2012:121) [1]. In this aspect of meaning, it does not focus only on production or economic activities but rather on "utility" and social order to strengthen resources based on the goals to be achieved, including in improving welfare and behavior patterns through the world of education and generational interest in making education. as a means of production or alternative to make evolutionary changes in maximizing utility. The impact of economic problems mostly touches on children's education, so that not a few families living in 
marginal settlements feel unable to send their children to school (Putro, 2007: 12) [4]. Then the declining condition of children's education becomes a major concern. For this reason, informal education is one option to revive their enthusiasm for education (Nugroho, 2017) [4].

On the other hand, to reveal the meaning of the term "marginal" cannot be separated from several circumstances including geographical conditions, economic conditions, and social conditions [2]. Variations in the condition of marginalized children can be seen from the variety and form of economic status, geographic location where a community group lives, or from the social conditions of the family and educational background [2]. Furthermore, the characteristics of marginalized children from the economic aspect include a) Children from poor families are mostly treated as work partners to help the family economy, b) School-age children (SD-SMP) from poor families have the opportunity to enjoy educational services in schools, c) Children who drop out of school due to high economic pressures causing them to be unable to bear the costs of education, such as committee fees, having to dress in uniform, buying school textbooks, practice fees, costs for other extracurricular activities[2]. Marginal means those who cannot adapt and involve themselves in the development process. They still struggle against suffering, hunger, injustice, alienation, and discrimination. Furthermore, having limited access and socio-economic capabilities in improving the situation is better than before, which consists of aspects of thought, action, and ideas. Marginalization can be based on various forms such as race, gender, sexual orientation, religious beliefs, physical disability, or economic or social status means alienating them, their views, and their needs to the periphery of society. So the marginalization of education here is a conscious or unconscious effort in the imbalance or exclusion of several regions/regions that are the same or different in fulfilling the elements of quality education, including teachers, students, facilities, access, and the environment based on consensus standardization.

\section{b. Habitus as an Educational Social Entity Arena}

As already mentioned, the condition of the Bajo Tribe fishing community which is categorized as marginal because it still lives in the suburbs of the Regency, and the uneven development of access and facilities as well as having limited education is far from the standardization it should be. Marginalization of Bajo Tribe children's education has occurred since the existence of the village from decades ago until now. This then results in a social impact on social change, adoption, and innovation that leads to the development and improvement of the quality of human resources in the Sulaho Village.

Based on information obtained from informants, that "Children are still less concerned about education because one of them is the influence of the school environment which is still not conducive to being occupied in the teaching and learning process because our school is still what it is".

In addition, according to the parents of the Bajo Tribe, "There is still a lack of development, so the children here are still just like that in the sense that they don't care about education".

The correlation in increasing motivation in learning or school is closely related to the readiness and availability of adequate facilities as one of the attractions to motivate students in learning, in addition to the carrying capacity of education staff who are ready to devote their knowledge and knowledge with the maximum effort by limited means. Due to these limitations in a short period, it shows that it is still far from serious attention in handling the quality of education itself in the region. The involvement of agencies and all components or apparatus of society, must take part and play an important role in making conditional efforts to motivate the sustainability of quality and independent education. These social institutions include families, government agencies, and other social institutions that will have a psychosocial effect on the behavior and character of children to stay in school as a playground and gain knowledge. According to Bourdieu, he sees the habitus is the key to 
social reproduction because it is central in generating and regulating the practices that shape social life. Individuals learn to desire what is possible for them, and not to aspire to what is not available to them. [14]. The environment is an integral part of supporting the learning process and is an attraction for the implementation of a good education. Bourdieu sees how power relations occur in certain societal structures and have an integral role in creating an arena in shaping cultural entities.

\section{c. Strategy for Alleviating Marginalization of Education}

Mythological And belief as a human sailor and living because of the sea, which has been engraved in the Bajo people, making the fishing profession the core of life and the life of the community. It's okay not to have anything from other natural resource wealth, as long as they have the sea, as long as they can carry out marine activities. This is transmitted to generations of Bajo Tribe children, that it is okay to be uneducated, or Education is only a compliment, the existence of this Tribe, from generation to generation is the activity of fishermen, so do not be surprised if the existence of this Tribe is almost in all regions in Indonesia still have a below-average education. Therefore, this must be a special concern for stakeholders, especially the government in alleviating the marginalization of education, both formal education and non-formal education.

Models and characteristics in conducting coaching make educational institutions varied and innovative in the implementation of learning to achieve and obtain maximum results. According to Meri Sandora [2], several institutions have the potential to guide marginalized children, namely: 1) Family Institutions; 2) School Education Institutions (Formal); 3) Educational Institutions in the Community (non-Formal); an education expert, Ki Hajar Dewantara, considers the institution to be the Tri-Center of Education, namely the Family Education Institution (informal), the School Education Institution (formal), and the Community Education Institution (non-formal) [15]. Of the three mentioned, it is an arena that is inseparable from human life in carrying out cultural activities as well as a source of knowledge in meeting both secondary and primary needs. This also happens to the children of the Bajo Sulaho Tribe who live and grow in coastal areas and live as fishermen with limitations from various aspects. If you refer to this, the three arenas above are also owned by the children of the Bajo Tribe in obtaining the same opportunities in the world of education as other children in different areas.

In realizing special character education for Bajo tribal children living in coastal areas, of course, they must have a contextual-based holistic education concept that describes regional characteristics and livelihoods. Based on observations and observations made in the study of the prospects for education in coastal areas, Bajo Tribe children living in coastal areas have great opportunities in the world of education without any marginalization. In addition to the three previously mentioned forms of education arena, the researcher sees the potential for education based on local wisdom based on the regional context where a person is located. Although this form of education model is also included in the category of non-formal education, specifically, it has several differences, especially if it is carried out with a curriculum based on the local wisdom of each culture. Local wisdom education here is transformational education between formal, informal, and non-formal knowledge about the livelihood specification environment.

Figure: Cultural Values in Educational Structures (Adapted from Zamroni 2011; Tatang M. Amirin; 2013).




Cultural values in the educational structure of environment-based local wisdom education or this education can also be said to be multicultural education and even this education has also been carried out in the United States [16], namely, the design of environmental education which can be interpreted as education that utilizes its environment or is environmentally oriented. Character education [17] itself does not have to damage the environment, for example by planting coral reefs, coral reef craftsmen, animal husbandry, reforestation and recycling of waste and the like, so that it can become an icon and characterizer of the region itself in producing valuable works or creations. economical. This educational approach is charged with strengthening related to the forms of attitudes that must be felt by students, namely awareness of identity, self-esteem, sensitivity to the suffering of others (empathy), love of truth (loving the good), self-control. (self-control), and humility(humility) [17].

\section{1) The Internalization Process of Values Believed by the Society}

The internalization process is a process that takes place from the time the individual is born until the moment he or she will die. Internalization is a process of inculcating cultural values [17]. The existence of empowerment efforts is one of the internalization processes that can be carried out to alleviate imbalances in the contextual-based educational structure. The inculcation of character values is not only centered on the educational process of the younger generation, but the task also lies in the individuals and the fabric of rationality over individuals in educational institutions (Koesoema, 2015:118) [18]. The process of internalizing character education in an educational institution cannot be done instantly, but gradually and carried out continuously or continuously [19]. The tendency of individuals to see values and is believed to be very closely related to the environment in which a person carries out social processes and seeks to adapt either directly or indirectly, this becomes a personality and characteristic in giving personality effects to oneself.

The environment is very influential on the development of a child, where the child's personality is formed due to environmental influences. If the environment is good, it will also be good for the child's personality. Children of the Bajo Tribe, as a fishing community that has a marine environment that is inseparable from the coast or the sea, it is very possible to become character values related to lifestyle and personality and be implemented in education based on local wisdom or the environment.

The egocentric relationship is based on the individual's necessity to focus on what actions feel good for him. Egocentrism claims that what is good for the individual is good for society. The orientation of egocentric ethics is not based on narcissism, but rather is based on a philosophy that focuses on individuals or private groups that stand-alone separately such as "social atoms".

\section{2) Empowerment Through Education Based on Local Wisdom}

Problems in the implementation of education, especially based on the environment of Sulaho Village, Lasusua, North Kolaka, which still lacks attention from various parties, including the local government, can be seen from the lack of educators, inadequate school facilities, the number of unemployed, lack of awareness and motivation from parents about the importance of education, and hopes and aspirations to improve education. future lifestyle and well-being.

Several important aspects must be considered in conducting empowerment based on local wisdom, namely:

a) Parental Awareness of

Education The first and foremost education in knowing something that is around us is in the family. Parents as family captains play an important role in shaping a person's character and personality. Therefore, parental awareness of education has the main key in opening horizons of thinking, building effective communication to realize character personality in the world of education. If parents have an awareness of the meaning of education, then the same has opened up opportunities in the sector mind to have a strong soul before entering the outside world (environment). 


\section{b) Government Policy Alignments The}

Role of the government as a supporting force in the implementation and succession of a good educational opportunity, because the government here, is not only present in providing policy management and implementation of education implementation, but is also involved in building and motivating Bajo tribal children and their parents, to maintain high awareness and motivation in education, and strive for adequate educational facilities.

\section{c) Utilization of the Environment for Education}

This idea was formed not only because the Bajo Tribe community is part of the coastal community, but also because very limited access to the use of coastal resources in the region has natural potential that can be explored and used as a tourism destination. Education-based on local wisdom. So with the use of the coastal environment, it will be one of the new models of education that unites the concept of informal, formal, and non-formal education. As part of efforts to empower the environment and the community, because the environment is very influential on the development of a child as a process of internalizing local cultural values and so that it remains sustainable and independent.

\section{CONCLUSION}

Education-based on local or environmental wisdom is an alternative to the existence of education that is not in favor of equity and balance in all levels of society, especially among marginalized groups, as an effort to obtain rights and obligations in improving their abilities and potential. Empowerment in the use of the environment for culture-based education is an innovation in character education that should receive special attention and treatment. This form of education hopes to provide opportunities for every child to get adequate education based on the constitutional mandate. To be easily accepted, the concept and curriculum are formatted according to the needs and values that are believed by the local community, so that the internalization process of personality character formation is easy to accept in all circles of society.

The strategies for alleviating the Marginalization of Education are 1) an effort to internalize the values that are believed by the community itself; 2) empowerment through education based on local wisdom which includes: parental awareness of education, partisanship with government policies, and utilization of the environment for education.

\section{ACKNOWLEDGMENTS}

The authors thank God Almighty for all the outpouring of grace so that researchers can finish this paper and try to publish it. Thank you also to the leadership of the Sociology Education Study Program and the Institute for Research, Development and Community Service the Muhammadiyah University of Makassar for providing opportunities and space, and letters to carry out research.

\section{REFERENCES}

[1] M. C. B. Umanailo, Marginalisasi Buruh Tani Akibat Alih Fungsi Lahan. 2017.

[2] M. Sandora, "Konsep Pendidkan Anak Marginal Dalam Perspektif Pendidikan Berbasis Masyarakat," Marwah J. Perempuan, Agama dan Jender, vol. 18, no. 2, p. 196, 2020, doi: 10.24014/marwah.v18i2.7588.

[3] P. R. Indonesia, D. Rahmat, T. Yang, and M. Esa, "Presiden republik indonesia, dengan rahmat tuhan yang maha esa," no. 1, pp. 1-17, 1989, [Online]. Available: https://jdih.setkab.go.id/PUUdoc/4220/UU NO 2 TH 1989.pdf.

[4] J. Sosiologi and U. S. K. Volume, "Inovasi Pendidikan pada Kaum Marginal," J. Sosiol. USK (Media Pemikir. Apl., vol. 12, no. 1, pp. 38-54, 2018, doi: 10.24815/jsu.

[5] J. W. Cresswell, Research Design Pendekatan Kualitatif, Kuantitatif, dan Mixed Edisi ketiga. 2017.

[6] H. M. B. Bungin, Metodologi Penelitian Kuantitatif: Edisi Kedua. 2005. 
[7] Sugiyono, Metode Penelitian Kombinasi (mixed Methods). 2018.

[8] A. . Fallis, John Cresswell - Research Design. 2013.

[9] B. Bungin, Analisis Data Penelitian Kualitatif Pemahaman Filosofis dan Metodologis ke Arah Penguasaan Model Aplikasi. 2007.

[10] P. D. Sugiyono, metode penelitian kuantitatif, kualitatif,dan R\&D. 2016.

[11] P. D. Sugiono, "Metode penelitian pendidikan pendekatan kuantitatif.pdf," Metode Penelitian Pendidikan Pendekatan Kuantitatif, Kualitatif Dan R\&D. 2014.

[12] M. P. Kualitatif, "Imam Gunawan," pp. 1-14, 2013.

[13] H. Wijaya, “Analisis Data Kualitatif Model Spradley,” Res. Gate, no. March, pp. 1-9, 2018, [Online]. Available: https://www.researchgate.net/publication/323557072.

[14] V. Jolasa, "Pierre Bourdieu dan Pemikirannya tentang Habitus, Doxa dan Kekerasan Simbolik," Pierre Bourdieu dan pemikirannya tentang habitus, doxa dan kekerasan simbolik, pp. 1-11, 2009.

[15] I. M. Sugiarta, I. B. P. Mardana, A. Adiarta, and W. Artanayasa, "Filsafat Pendidikan Ki Hajar Dewantara (Tokoh Timur)," J. Filsafat Indones., vol. 2, no. 3, p. 124, 2019, doi: 10.23887/jfi.v2i3.22187.

[16] T. M. Amirin, “implementasi Pendekatan Pendidikan Multikultural Kontekstual Berbasis Kearifan Lokal di Indonesia," J. Pembang. Pendidik. Fondasi dan Apl., vol. 1, no. 1, 2013, doi: 10.21831/jppfa.v1i1.1047.

[17] S. Mislikhah, "Pendidikan Karakter Berbasis Kearifan Lokal," FALASIFA J. Stud. Keislam., vol. 11, no. 2, pp. 17-34, 2020, doi: 10.36835/falasifa.v11i2.368.

[18] M. Munif, "Strategi Internalisasi Nilai-Nilai Pai Dalam Membentuk Karakter Siswa," Edureligia; J. Pendidik. Agama Islam, vol. 1, no. 2, pp. 1-12, 2017, doi: 10.33650/edureligia.v1i2.49.

[19] E. Andayani, "Revitalisasi Nilai-Nilai Pendidikan Karakter,” vol. 4, no. 2, pp. 31-45, 2011. 